\title{
Memahami Profesi dan Profesional Guru
}

\author{
Yusup \\ Email: 2010128210007@mhs.ulm.ac.id \\ Program Studi Pendidikan IPS Fakultas Keguruan dan Ilmu Pendidikan \\ Universitas Lambung Mangkurat \\ Banjarmasin
}

\begin{abstract}
Abstrak
Profesi Guru ialah perkerjaan memajukan sesuatu dari dunia pendidikan dari adanya sosok Guru sebagai pendidik prepesional dengan tugas utama mendidik, mengajar, membimbing, mengarahkan, melatih, menilai, dan mengevaluasi perserrta didik Pada pendidikan anak usia dini dari jalur pendidikan formal,dasar, dan menengah yang aakan menghasilkan dari adanya profesi guru melahirkan para generasi berpendidikan yang mana sangat penting bagi sebuah bangsa karena dengan berpendidikan lah bangsa ini menjadi lebih baik dalam mencerdasarkan penerus bangsa. Profesional Guru sangat diperlukan terhadap kemajuan pendidikan Indonesia sebab masih adanya kualitas guru yang sangat harus di tingkatan agar dapat menjadi suatu tenaga pendidik dengan kualitas baik dapat menjadikan perserta didik dan sebaginya dapat menjadi suatu yang akan menjadi lebih baik dalam menjalani dunia pendidikan dan juga di kehidupannya
\end{abstract}

\section{PENDAHULUAN}

Profesi dari bahasa etimologi berasal dari kata profession (inggris) berasal dari bahasa Latin profesus yang berarti "Mampu atau ahli dalam suatu bentuk pekerjaan". Profesi dapat diartikan sebagai adanya suatu pekerjaan atau jabatan yang menuntut keahlian dalam bidangnya yang mana diperoleh dari suatu pendidikan maupun latihan-latiahan. Menurut persyaratan khusus memiliki tanggung jawab dan kode etik yang sudah ditentukan dan ditetapkan. Pekerjaan yang memiliki sifat profesional pastinya berbeda dengan pekerjaan yang lain nya sebab adanya suatu profesi pastinya memerlukan keterampilan dan keahlian khusus dalam menjalankan suatu profesinya. Profesi juga merupakan suatu jabatan atau pekerjaan tertentu yang mensyaratkan pengetahuan dan keterampilan khusus yang diperoleh dari pendidikan akademis yang intensif. Jadi profesi adalah suatu pekerjaan atau jabatan yang menuntut keahlian tertentu dan dapat menjadi suatu yang akan di pertangung jawabkan. Guru ialah tenaga pendidik yang memiliki tugas utamanya sebagai sosok mendidik, 
mengajar, membimbing, melatih dan mengevaluasi agar memperoleh sesuatu hal yang diinginkan bagi perserta didik. ( Susanto, H. 2020: 11).

Profesi ialah suatu jabatan atau pekerjaan yang menuntut keahlian (expertise) dari para keanggotannya sebab tidak bisa dilakukan oleh orang yang tidak dilatih dan tidak persiapkan secara khusus dalam melaksankaan pekerjaan tersebut. Suatu profesi erat kaitannya dengan jabatan atau pekerjaan tertentu yang dengan sendirinya menuntut keahlian, pengetahuan dan keterampilan tertentu pula. ( Pane, S. H. B. 2019: 20 ). Menurut De George Profesi juga mengemukanan bahwa profesi ialah suatu pekerjaan yang dijalankan sebagai aktifitas pokok untuk memperoleh sebuah hasilkan bagi kehidupan. ( Isnanto, R. R. 2009).

Jadi Profesi ialah suatu perkerjaan yang mempunyai keahlian dalam perkerjaannya sebab memiliki tanggung jawab terhadap ketentuan-ketentuan yang sudah ditetapkan dan dalam pelaksanannya memerlukan kemampuan dan keahlian khusus sebab tidak adanya keahlian maupun kemampuan yang khusus tidak akan memperoleh terhadap perserta didik yang nantinya di harapkan dan hal hal yang tidak diinginkan akan terjadi pada dunia pendidikan dan kehidupan sekitar. Profesi itu di peroleh dari pendidikan akademis sebab sudah adanya ketentuan ketika dalam menjalakan pendidikannya. Sedangkan yang bukan Profesi itu ialah perkerjaan tidak mempunyai keahlian dalam perkerjaan sebab dalam pelaksaanan tidak memenerlukan kemampuan yang khusus akan tetapi apa yang ada saja karena di peroleh dari tidak ada pendidikan juga tidak jadi masalah.

Profesi guru ialah perkerjaan yang dapat menentukan kehidupan masa depan bangsa sebab adanya keahlian Guru yang memiliki penguasaan terhadap bahan pelajaran, memiliki strategi pembelajaran dengan terencana dengan baik, memiliki mendorong suatu peserta didik dalam belajar untuk mencapai suatu prestasi yang tinggi dan sangat membanggakan akan tetapi dari segala upaya dalam meningkatan suatu kualitas pendidikan. Guru yang profesional minimal pastinya memiliki kepastian dengan tanggung jawab terhadap kepada peserta didik dan suatu proses belajarnya, menguasai bahan pelajaran dengan sangat baik yang akan diajarkannya, serta dengan cara dalam penyampaiannya kepada perserta didik, dan bertanggung jawab dalam memperoleh hasil belajar perserta didik dalam berbagai teknik evaluasi sebab agar dapat terjaga apa yang sudah didapatkan, serta mampu bisa berpikir secara sistematis tentang suatu yang dijalankan, mengadakan koreksi sebab akan mengetahui peningkatan hasil dari perserta didik dapatkan, belajar dari suatu pengalaman yang mana nantinya dampaknya akan terlihat pada proses belajar mengajar, dan berjalan mau ialah bagian dari masyrakat belajar dalam lingkungan profesinya sehingga nantinya akan menjadi berhubungan yang luas dan profesional. ( Susanto, H. 2020: 10).

Profesi guru ialah perkerjaan yang sangat penting dan berkontribusi langsung terhadap kemajuan suatu bangsa sebab dengan adanya suatu profesi dari sosok guru yang sempurna dalam memiliki syarat-syarat atau ketentuan khusus untuk dapat dijalani oleh seseorang. Perlunya suatu kompetensi khusus untuk menjadi seorang guru sebab Guru ialah memiliki sosok yang berpengaruh bagi pemberdayaan dan pembelajaran suatu bangsa yang 
tidak mungkin digantikan oleh unsur manapun dalam kehidupan sebuah bangsa sejak dahulu karena guru di masa sekarang dan gerak maju dinamika kehidupan sangat bergantung dari "citra" guru di tengah-tengah masyarakat. ( Susanto, H. 2020: 42 ).

Jadi Profesi Guru ialah perkerjaan memajukan sesuatu dari dunia pendidikan dari adanya sosok Guru sebagai pendidik prepesional dengan tugas utama mendidik, mengajar, membimbing, mengarahkan, melatih, menilai, dan mengevaluasi perserrta didik Pada pendidikan anak usia dini dari jalur pendidikan formal,dasar, dan menengah yang aakan menghasilkan dari adanya profesi guru melahirkan para generasi berpendidikan yang mana sangat penting bagi sebuah bangsa karena dengan berpendidikan lah bangsa ini menjadi lebih baik dalam mencerdasarkan penerus bangsa.

\section{PERAN GURU SEBAGAI SEBUAH PROFESI}

Guru sesuai syarat suatu pekerjaan untuk dapat digolongkan menjadi suatu profesi yaitu ( Susanto, H. 2020: 12) Memiliki spesialisasi ilmu sebab setiap profesi atau perkerjaan yang sesuai keilmuan rancang berdasarkan kekhususan keilmuan karena sehingga orang yang masuk dalam suatu bidang profesi pastinya memiliki latar belakang keilmuan yang sesuai dengan keahliannya. Dengan ini menjelaskan sesuatu itu tidak lah sembarang orang dapat bekerja di suatu bidang profesi karena harus memiliki keilmuan yang relevan. Adanjua memiliki kode etik dalam menjalankan suatu profesi sebab kode etik ialah sebagai pedoman etik/pedoman moral bagi anggota profesi dalam menjalankan tugasnya. Kode etik profesi diperlukan untuk menjaga martabat dan menjadi pedoman bagi insan profesi dalam menjalankan profesinya agar berjalan dengan baik dan tidak ada hal hal yang tidak di inginkan. Perlunya memiliki organisasi profesi sebeb organisasi ialah tempat untuk perjuangan dan perkumpulan insan profesi untuk menjalin intraksi. Dan adanya suatu organisasi profesi yang memiliki fungsi untuk pengembangan profesi melalui sharing inovasi dan komunikasi suatu profesi untuk memajukan sesuatu untuk nantinya di jalankan dan melalui organisasi ini lah sesorang yang berprofesi akan memiliki kesepakatan yang sama dalam menjalankan profesinya dan memiliki kemampuan untuk merespon berbagai kebijakan dan tantangan terkait profesi dan dapat menjadi simbol terkuatnya dalam suatu profesi di tengah lingkungan masyarakat sebab suatu profesi harus mendapat pengakuan masyarakat. Pengakuan ini diperoleh jika profesi tersebut telah terbukti memiliki peran sesuai bidangnya. Pengakuan masyarakat ialah suatu bentuk legimitasi terhadap keberadaan dan peran suatu profesi untuk membantu penyesuaian dalam permasalahan yang ada di tengah masyarakat. Ada jua sebagai panggilan hidup karena profesi ialah karir sepanjang hayat, dengan demikian profesi akan mendarah daging bagi orang yang menjalankannya.

Adanya Syarat-syarat suatu profesi pastinya melibatkan suatu aktivitas intelektual. menggeluti suatu batang tubuh ilmu yang khusus dan pasttinya memerlukan persiapan profesional yang alami dan bukan sekedar latihan agar terhindar dari tidak adanya hal hal 
yang tidak di inginkan dan memerlukan latihan sebagai nantinya menjadi suatu yang di harapkan dalam menjalankan yang berkesinambungan untuk memastikan dari perkerjaan dari hidup seseorang dan keanggotaan yang permanen dan adanya mementingkan layanan di atas keuntungan pribadi sebab adanya kepentingan yang harus dimiliki. adanya organisasi profesional yang kuat dan terjalin erat agar dapat menjadikan suatu hal yang diinginkan. menentukan baku standarnya sendiri dalam hal ini ialah kode etik. ( Isnanto, R. R. 2009: 12).

Guru ialah salah satu di antara profesi di bidang pendidikan. Dalam Undang-Undang No. 14 Tahun 2005, Guru ialah pendidik profesional dengan tugas utama mendidik, mengajar, membimbing, mengarahkan, melatih, menilai, dan mengevaluasi peserta didik pada pendidikan anak usia dini jalur pendidikan formal, pendidikan dasar, dan pendidikan menengah. Guru ialah seseorang yang memiliki tugas terkait dengan upaya mencerdaskan kehidupan bangsa dalam semua aspeknya, baik spiritual dan emosional, intelektual, fisikal, maupun aspek lainnya. Jika diidentifikasi dari filosofi pendidikan Indonesia yang dicetuskan Ki Hadjar Dewantara "ing ngarso sung tulodo, ing madya mangun karso, tutwuri handayani" maka Guru memiliki peran sebagai Role model (ing ngarso sung tulodo) yang mana guru memberikan teladan kepada perserta didik sebeb fungsi guru menjadi suatu pemimpin bagi perserta didik dalam aktivitas pembelajaran. Ada juga sebagai motor penggerak (ing madya mangun karso) yang mana sosok guru harus menjadi penggerak inovasi dalam proses pendidikan dan penggerak peradaban dengan cara membimbingan perserta didik untuk melakukan yang benar sesuai dengan ketentuan. Ada juga sebagai Motivator (tutwuri handayani) yang mana guru mampu memberikan dorongan semangat terhadap perserta didik untuk mengadapi setiap persoalan/permasalahan dan mempelajari nilai-nilai kehidupan agar dapat menjadikan perserta didik yang dapat menyelesaikan dengan baik. ( Susanto, H. 2020: $31)$

Menurut Hamalik, ( Fadhila, N. 2017: 6 ) Guru dapat menjalankan perannya yaitu: Sebagai fasilitator yang siap selalu dalam menyediakan suatu kemudahan bagi perserta didik untuk melakukan kegiatan belajarnya. Sebagai pembimbing yang mana guru membantu perserta didik mengatasi kesulitan dalam proses belajar sebab jika tidak di bantu dapat menjadikan perserta didik kehilangan arah, Sebagai penyedia lingkungan yang mana Guru seallu berupaya menciptakan lingkungan yang menantang peserta didik agar melakukan kegiatan belajar dengan baik, Sebagai komunikator yang mana Guru melakukan komunikasi dengan siswa dan masyarakat sebab dengan adanya intraksi maka akan menjadikan suatu terjalin hubungan baik dalam memberikan terbaik terhadap sekitarnya, Sebagai model yang mana Guru mampu memberikan contoh yang baik kepada perserta didiknya agar berprilaku yang baik sebab dengan adanya contoh yang baik maka akan menjadikan perserta didik memiliki keperilakuan sangat berkualitas, Sebagai evaluator yang mana Guru melakukan penilaian terhadap kemajuan belajar siswa sebab dengan hal itu pastinya akan mengetahui perserta didik dalam proses pembalajaran apa kah sudah didapatkan oleh perserta didik itu, Sebagai inovator yang mana Guru turut menyebarluaskan usaha pembaruan kepada 
masyarakat sebab adanya kekuraangan pengetahuan masyarakat mengenai hal hal yang baru yang terjadi, Sebagai motivator yang mana Guru meningkatkan kegairahan dan pengembangan kegiatan belajar siswa sebab dengan adanya suasana yang damai akan menghasilakan sesuatu yang bisa menjadi seusatu peningkatan terhadap yang akan di sampaikan dan diberikan terhadapa perserat didik. Sebagai agen kognitif, yang menyebarkan ilmu pengetahuan kepada peserta didik dan masyarakat sebab dengan adanya pealuran ilmu itu menjadikan di tenagah masyarakat tidak ketertinggalan akan apa yang baru yang nantinya mereka hadapi, Sebagai Penilaian atau evalusi yanga maana Guru menjadi suatu aspek dalam pembelajaran yang paling kompleks sebab melibatkan banyak latar belakang dan hubungan. Jadi Peran guru itu sangatlah penting dalam pendidikan sebab sangat membantu perserta didik dalam menyelesaikan maupun mengatasi kesulitan dalam proses belajar yang sering terjadi perubahan akibat dari berjalannya waktu kewaktu dalam dunia pendiidkan yang berupaya menciptakan lingkungan yang menantang perserta didik agar melakukan kegiatan belajar dengan sebaik baiknya agar hal hal yang tidak diinginkan dapat tidak terjadi.

Hak Guru ialah dalam menjalankan tugas dan profesinya pastinya guru memiliki hak dan kewajiban yang harus dilaksanakan dan diperhatikan dengan sebaik baiknya. Hak guru ialah suatu yang harus dimiliki dan diperoleh dengan semestinya setelah menjalankan sejumlah kewajibannya sebagai guru. Dalam UU No. 14 Tahun 2005 tentang guru dan dosen pada bagian kedua mengenai hak dan kewajiban pada pasal 14, adapun hak yang dimiliki oleh seorang guru sebagai berikut memperoleh penghasilan di atas kebutuhan hidup minimum dan jaminan kesejahteraan sosial sebab dengan adanya suatu penghasilan itu lah memberikan bantuan kebutuhan dalam menjalankan apa yang sudah ditetapkan agar menghasilakan suatu hal yang di inginkan. Ada juga hak guru mendapatkan promosi dan penghargaan sesuai dengan tugas dan prestasi kerja sebab dengan itu menjadikann guru akan meningkatan apa yang harus di tingkan kan untuk menjadi lebih baik dari seblumnya. Hak Guru juga memperoleh perlindungan dalam melaksanakan tugas dan hak atas kekayaan intelektual sebab dengan adanya perlindungan menjadikan guru merasa lebih baik daalam menjalankan tugasnya. Hak Guru juga memperoleh kesempatan untuk meningkatkan kompetensi sebab dengan adanya kesempatan menjadi guru akan memiliki suatu kualitas nya menjadi suatu sangat berkualitas. Hak Guru juga memperoleh dan memanfaatkan sarana dan prasarana pembelajaran dalam menunjang kelancaran tugas keprofesionalan sebab dengan itu lah guru sangat terbantu yang akibanya akan menjadi lebih baik dalam menjalankan tugas tugasnya. Hak Guru yang mana memiliki kebebasan dalam memberikan penilaian dan ikut menentukan kelulusan, penghargaan, dan atau sanksi kepada peserta didik sesuai dengan kaidah pendidikan, kode etik guru, dan peraturan perundang-undangan sebab ddengan itu lah adanya suatu kekuasaan guru dalam merencanakan maupun menciptakan sesuatu dengan baik sesaui dengan ketentuan. Hak Guru juga memperoleh rasa aman dan jaminan keselamatan dalam melaksanakan tugas sebab dengan adanya rasa amaan akan menjadikan suatu hal hal yang tidak di inginkan dapat terlaksana dengan sangat baik. Hak Guru juga 
memiliki kebebasan untuk berserikat dalam organisasi profesi dengan itu lah menjadikan jamianan nantinya terhadap yang akan terjadi kedepannya. Hak Guru juga memiliki kesempatan untuk berperan dalam penentuan kebijakan pendidikan sebab guru lah orang yang menjadi sosok yang melaksankan nya maka adanya suatu masukan pendapat terhadap suatu kebijakan yang akan di tetapkan. Hak Guru juga memperoleh berbagai kesempatan untuk mengembangkan dan meningkatkan kualifikasi akademik dan kompetensi sebab itu lah menjaidkan kulitas sangat baik terhadap guru yang akan menjadi pemimpin terhadap perserta didik dan lain lainnya. Hak Guru juga memperoleh pelatihan dan pengembangan profesi dalam bidangnya agar menjadi suatu peningkatan apa yang menjadi suatu yag dijaikan menjadi lebih baik. Jika Hak guru dalam menjalankan profesinya sudah sangat baik maupun meliputi hak hidup kesejahtera, hak perlindungan, hak kebebasan , hak berserikat, dan hak pengembangan dan sebagainya. Jadi Hak Guru itu haruslah didapatkan agar membuat guru merasa aman dalam menjalankan profesinya dan dapat berkontribusi maksimal dalam memajukan pendidikan dengan sebaik baiknya.

Kewajiban Guru dalam melaksanakan tugas keprofesionalan dalam UU No. 14 tahun 2005 tentang guru dan dosen, pada pasal 20 maka guru berkewajiban sebagai Perencana dalam pembelajaran, melaksanakan proses pembelajaran yang bermutu, serta menilai dan mengevaluasi hasil pembelajaran. mengembangkan dan meningkatkan kualifikasi akademik dan kompetensi secara berkelanjutan sejalan dengan perkembangan ilmu pengetahuan, teknologi dan seni. Bertindak objektif dan tidak diskriminatif atas dasar pertimbangan jenis kelamin, agama, suku, ras, dan kondisi fisik tertentu, atau latar belakang keluarga, dan status sosial ekonomi peserta didik dalam pembelajaran Menjunjung tinggi peraturan perundang undangan, hukum dan kode etik guru, serta nilai nilai agama dan etika. Dan memelihara serta memupuk persatuan dan kesatuan bangsa. Jadi Kewajiaban Guru harus bertanggung jawab atas segala sikap, tingkah laku, dan perbuatannya dalam rangka membina dan watak perserta didik. Agar menjadi tanggung jawab guru untuk membentuk perserta didik agar menjadi orang memiliki keperibadian yang cakap dalam berintraksi yang dapat berguna bagi agama, nusa, dan bangsa dimasa yang akan datang.

\section{GURU INDONESIA DAN TANTANGAN PROFESIONALISME}

Profesionalisme ialah suatu kata yang menunjukan kepada sikap mental terhadap bentuk komitmen pada para sesorang profesi yang senantiasa dalam mewujudkan maupun meningkatkan kualitas profesionalnya. Sedangkan Profesionalisme guru ialah sebuah pencerminan sikap mental serta komitmenya dalam perwujudan maupun peningkatan kualitas kompetensi keguruannya dengan segala upaya yang sangat baik, strategi dan senantiasa pengembangan kemampuan dirinya yang sesuai dengan suatu kemajuan masa ke masa sehingga keberadaannya senantiasa memberikan makna (Rudi, 2014). Sedangkan Menurut Makawimbang (2011: 134) guru yang profesional adalah mereka yang memiliki 
kemampuan profesional dengan berbagai kapasitasnya sebagai pendidik. Guru profesional memiliki pengalaman mengajar, kapasitas intelektual, moral, keimanan, ketakwaan, disiplin, tanggung jawab, wawasan kependidikan yang luas, kemampuan manajerial, terampil, kreatif, memiliki keterbukaan profesional dalam memahami potensi, karakteristik dan masalah perkembangan peserta didik, mampu mengembangkan rencana studi dan karir peserta didik serta memiliki kemampuan meneliti dan mengembangkan kurikulum. ( Sastrawan, K. B. 2016: 1 ). Jadi Profesional Guru sangat diperlukan terhadap kemajuan pendidikan Indonesia sebab masih adanya kualitas guru yang sangat harus di tingkatan agar dapat menjadi suatu tenaga pendidik dengan kualitas baik dapat menjadikan perserta didik dan sebaginya dapat menjadi suatu yang akan menjadi lebih baik dalam menjalani dunia pendidikan dan juga di kehidupannya

Kompetensi profesional guru ialah kemampuan dan kewenangan guru dalam menjalankan profesi keguruannya sebab guru yang ahli dalam menjalankan profesinya dapat dikatkan sebagai guru yang berkualitas dan profesional. Kompetensi profesional ialah pekerjaan yang bisa dapat di lakukan oleh seorang yang mempunyai kualifikasi akademik, kompetensi dan sertifikat pendidik sesuai dengan persyaratan untuk setiap jenis dan jenjang pendidikan tertentu. ( Susanto, H. 2020: 51 ).

Kompetensi Guru Dalam Undang-undang Republik Indonesia Nomor 14 tahun 2005 Tentang Guru dan Dosen, kompetensi adalah seperangkat pengetahuan, keterampilan, dan perilaku yang harus dimiliki, dihayati, dan dikuasai oleh guru dalam melaksanakan tugas keprofesionalan. Kompetensi yang harus dimiliki oleh guru berdasarkan Undang-Undang Nomor 14 Tahun 2005 tentang Guru dan Dosen yang disampaikan bahwa suatu Kompetensi guru yang meliputi ( Sastrawan, K. B. 2016: 68 ). kompetensi pedagogik ialah suatu kemampuan guru yang sangat baik dalam pengelolaan pembelajaran peserta didik yang berkenanan mengenai pemahaman wawasan atau landasan kependidikan, Pemahaman terhadap peserta didik, Pengembangan dalam kurikulum, Perancangan pembelajaran, Pelaksanaan pembelajaran yang mendidik dan dialogis, Pemanfaatan teknologi pembelajaran, Evaluasi suatu hasil dari belajar, dan Pengembangan peserta didik untuk mengaktualisasikan berbagai potensi yang dimilikinya. Jadi Kompetensi Pedagogik ialah adanya keahlian dari sosok seorang guru dalam proses pembelajaran yang menekankan suatu pengelolaan yang sangat terencana baik agar dapat dipahami juga dapat memanfaatkann suatu saran dan prasarana agar nantinya menghasilkan sesuatu hal hal yang di inginkan terhadap perserta didik.

Kompetensi kepribadian ialah kemampuan kepribadian yang sangat baik yang berkenanan Beriman dan bertakwa, memiliki akhlak mulia, memiliki bijaksana, memiliki demokratis, punya kewibawaan, Stabil, Dewasa, keJujuran, Sportif, menjadi teladan bagi peserta didik dan masyarakat, mengevaluasi kinerja sendiri, dan mengembangkan diri secara mandiri dan berkelanjutan. Jadi Kompetensi keperibadian ialah adanya keahlian dari sosok 
seorang guru dalam membangun keperibadian perserta didik dalam mengembangkan dirinya agar menjadikan sangat berkualitas.

Kompetensi sosial iaalah kemampuan guru yang menjadi bagian dari suatu masyarakat yang meliputi kompetensi untuk berkomunikasi lisan, tulis, dan/atau isyarat secara santun, Menggunakan teknologi komunikasi dan informasi secara fungsional, secara efektif dengan peserta didik, sesame pendidik, tenaga kependidikan, pimpinan satuan pendidikan, orang tua atau wali peserta didik, santun dengan masyarakat sekitar dengan mengindahkan norma serta sistem nilai yang berlaku, menerapkan prinsip persaudaraan sejati dan semangat kebersamaan.Jadi Kompetensi sosial ialah adanya keahlian dari sosok seorang guru dalam berintraksi dengan sangat baik terhadap perserta didik yang mana nantinya akan menjadi intraksi baik terhadap masyarakat sekitar.

Kompetensi professional ialah suatu kemampuan guru dari pengguasai pengetahuan bidang ilmu pengetahuan, teknologi, dan/atau seni dan budaya yang diampunya yang berkenaan penguasaan materi pelajaran secara luas dan mendalam sesuai dengan standar isi program satuan pendidikan, mata pelajaran, dan/atau kelompok mata pelajaran yang akan diampu dan memiliki konsep dan metode disiplin keilmuan, teknologi, atau seni yang relevan, yang secara konseptual menaungi atau koheren dengan program satuan pendidikan, mata pelajaran, dan/atau kelompok mata pelajaran yang akan diampu. Sedangkan Pandangan ahli tentang kompetensi profesional guru. Menurut Cooper (1984:15) mengumukanan empat komponen ialah mempunyai pengetahuan tentang belajar dan tingkah laku manusia, mempunyai pengetahuan dan menguasai bidang studi yang dibinanya, mempunyai sikap yang tepat tentang diri sendiri, madrasah, teman sejawat, dan bidang studi yang dibinanya, dan mempunyai keterampilan dalam teknik mengajar. (Arifin, Z. 2020: 24 ). Jadi Kompetensi profesional ialah adanya keahlian dari sosok seorang guru berkenan dalam penguasaan yang akan di ajarkan kepada perserta didik yang mana hasilakan akan menjadi sebuah suatu perubahan yang akan menjadi lebih baik terhadap perserta didik.

Kompetensi kepemimpinan yang kemukakan pada Peraturan Menteri Agama Nomor 16 Tahun 2010 meliputi: Kemampuan membuat perencanaan pembudayaan pengamalan ajaran agama dan perilaku akhlak mulia pada komunitas sekolah sebagai bagian dari proses pembelajaran agama, Kemampuan mengorganisasikan potensi unsur sekolah secara sistematis untuk mendukung pembudayaan pengamalan ajaran agama pada komunitas sekolah, Kemampuan menjadi inovator, motivator, fasilitator, pembimbing dan konselor dalam pembudayaan pengamalan ajaran agama pada komunitas sekolah, serta Kemampuan menjaga, mengendalikan, dan mengarahkan pembudayaan pengamalan ajaran agama pada komunitas sekolah dan menjaga keharmonisan hubungan antar pemeluk agama dalam bingkai Negara Kesatuan Republik Indonesia. Jadi Kompetensi kepemimpinan ialah adanya keahlian dari sosok seorang guru berkenan dari pengalaman dari berbagai kegiatan luar yang akan menjadi sebuat tambahan keahlian guru dalam mengajarkan terhadap perserta didik. 


\section{SIMPULAN}

Profesi ialah suatu perkerjaan yang mempunyai keahlian dalam perkerjaannya sebab memiliki tanggung jawab terhadap ketentuan-ketentuan yang sudah ditetapkan dan dalam pelaksanannya memerlukan kemampuan dan keahlian khusus sebab tidak adanya keahlian maupun kemampuan yang khusus tidak akan memperoleh terhadap perserta didik yang nantinya di harapkan dan hal hal yang tidak diinginkan akan terjadi pada dunia pendidikan dan kehidupan sekitar. Profesi itu di peroleh dari pendidikan akademis sebab sudah adanya ketentuan ketika dalam menjalakan pendidikannya. Sedangkan yang bukan Profesi itu ialah perkerjaan tidak mempunyai keahlian dalam perkerjaan sebab dalam pelaksaanan tidak memenerlukan kemampuan yang khusus akan tetapi apa yang ada saja karena di peroleh dari tidak ada pendidikan juga tidak jadi masalah.

Profesi Guru ialah perkerjaan memajukan sesuatu dari dunia pendidikan dari adanya sosok Guru sebagai pendidik prepesional dengan tugas utama mendidik, mengajar, membimbing, mengarahkan, melatih, menilai, dan mengevaluasi perserrta didik Pada pendidikan anak usia dini dari jalur pendidikan formal,dasar, dan menengah yang aakan menghasilkan dari adanya profesi guru melahirkan para generasi berpendidikan yang mana sangat penting bagi sebuah bangsa karena dengan berpendidikan lah bangsa ini menjadi lebih baik dalam mencerdasarkan penerus bangsa.

Guru dapat digolongkan sebagai profesi sebab guru memiliki spesialisasi ilmu yaitu profesinya dibangun berdasarkan kekhususan ilmu yang sesuai dan relavan karena memiliki kode etik dalam menjalankan profesi karena suatu pedomaan etik dan moral untuk menjaga martabat dan menjadikan pedoman bagi insan profesi dalam menjalankan profesinya.

Peran guru itu sangatlah penting dalam pendidikan sebab sangat membantu perserta didik dalam menyelesaikan maupun mengatasi kesulitan dalam proses belajar yang sering terjadi perubahan akibat dari berjalannya waktu kewaktu dalam dunia pendiidkan yang berupaya menciptakan lingkungan yang menantang perserta didik agar melakukan kegiatan belajar dengan sebaik baiknya agar hal hal yang tidak diinginkan dapat tidak terjadi. Hak Guru itu haruslah didapatkan agar membuat guru merasa aman dalam menjalankan profesinya dan dapat berkontribusi maksimal dalam memajukan pendidikan dengan sebaik baiknya. Kewajiaban Guru harus bertanggung jawab atas segala sikap, tingkah laku, dan perbuatannya dalam rangka membina dan watak perserta didik. Agar menjadi tanggung jawab guru untuk membentuk perserta didik agar menjadi orang memiliki keperibadian yang cakap dalam berintraksi yang dapat berguna bagi agama, nusa, dan bangsa dimasa yang akan datang.

Profesional Guru sangat diperlukan terhadap kemajuan pendidikan Indonesia sebab masih adanya kualitas guru yang sangat harus di tingkatan agar dapat menjadi suatu tenaga pendidik dengan kualitas baik dapat menjadikan perserta didik dan sebaginya dapat menjadi 
suatu yang akan menjadi lebih baik dalam menjalani dunia pendidikan dan juga di kehidupannya

Kompetensi Pedagogik ialah adanya keahlian dari sosok seorang guru dalam proses pembelajaran yang menekankan suatu pengelolaan yang sangat terencana baik agar dapat dipahami juga dapat memanfaatkann suatu saran dan prasarana agar nantinya menghasilkan sesuatu hal hal yang di inginkan terhadap perserta didik. Kompetensi keperibadian ialah adanya keahlian dari sosok seorang guru dalam membangun keperibadian perserta didik dalam mengembangkan dirinya agar menjadikan sangat berkualitas. Kompetensi sosial ialah adanya keahlian dari sosok seorang guru dalam berintraksi dengan sangat baik terhadap perserta didik yang mana nantinya akan menjadi intraksi baik terhadap masyarakat sekitar. Kompetensi profesional ialah adanya keahlian dari sosok seorang guru berkenan dalam penguasaan yang akan di ajarkan kepada perserta didik yang mana hasilakan akan menjadi sebuah suatu perubahan yang akan menjadi lebih baik terhadap perserta didik. Kompetensi kepemimpinan ialah adanya keahlian dari sosok seorang guru berkenan dari pengalaman dari berbagai kegiatan luar yang akan menjadi sebuat tambahan keahlian guru dalam mengajarkan terhadap perserta didik.

\section{REFERENSI}

Efendi, I., Prawitasari, M., \& Susanto, H. (2021). Implementasi Penilaian Pembelajaran Pada Kurikulum 2013 Mata Pelajaran Sejarah. Prabayaksa: Journal of History Education, 1(1), 21-25.

Susanto, H. (2020). Profesi Keguruan. Banjarmasin: FKIP Universitas Lambung Mangkurat.

Susanto, H., \& Akmal, H. (2018). Efektivitas Penggunaan Aplikasi Pembelajaran Berbasis Mobile Smartphone Sebagai Media Pengenalan Sejarah Lokal Masa Revolusi Fisik Di Kalimantan Selatan Pada Siswa Sekolah Menengah Atas. HISTORIA: Jurnal Program Studi Pendidikan Sejarah, 6(2), 197-206.

Susanto, H., Irmawati, I., Akmal, H., \& Abbas, E. W. (2021). Media Film Dokumenter Masuknya Islam Ke Nusantara dan Pengaruhnya Terhadap Keterampilan Berpikir Kritis Siswa. HISTORIA: Jurnal Program Studi Pendidikan Sejarah, 9(1).

Syaharuddin, S., \& Susanto, H. (2019). Sejarah Pendidikan Indonesia (Era Pra Kolonialisme Nusantara sampai Reformasi). Banjarmasin: FKIP Universitas Lambung Mangkurat.

Isnanto, R. R. (2009). Buku ajar etika profesi.

Pane, S. H. B. (2019). Profesionalitas guru dalam pengembangan materi pendidikan Agama Islam Di Mts Lkmd Kasikan Kecamatan Tapung Hulu Kabupaten Kampar (Doctoral dissertation, IAIN Padangsidimpuan). 
Sopian, A. (2016). Tugas, Peran, dan Fungsi Guru dalam Pendidikan. Raudhah Proud To Be Professionals: Jurnal Tarbiyah Islamiyah, 1(1), 88-97.

Fadhila, N. (2017). PERAN GURU PENDIDIKAN AGAMA ISLAM SEBAGAI MOTIVATOR BELAJAR SISWA DI SMA NEGERI 8 BANDAR LAMPUNG (Doctoral dissertation, UIN Raden Intan Lampung).

Sastrawan, K. B. (2016). Profesionalisme guru dalam upaya meningkatkan mutu pembelajaran. Jurnal Penjaminan Mutu, 2(2), 65-73.

Mas, S. R. (2008). Profesionalitas Guru dalam Peningkatan Kualitas Pembelajaran. Jurnal Inovasi, 5(2).

Arifin, Z. (2020). Strategi Komunikasi Pengawas Dalam Meningkatkan Kemampuan Profesionalisme Guru Di Madrasah Ibtidaiyah Negeri 15 Langkat (Doctoral dissertation, Universitas Islam Negeri Sumatera Utara). 